\title{
The Conflicts of Worship Houses after the Reformation in North Sumatra, Indonesia
}

\author{
Dr. Arifinsyah, M.Ag \\ Ushuluddin Faculty and Islamic Studies, State University of North Sumatra (UINSU), Medan, Indonesia
}

\begin{abstract}
The diversity of religious communities in North Sumatra Province demographically based on religion and ethnicity occupies one of the plural provinces in Indonesia. The population demographics based on religion and ethnicity in some urban districts show high differences, some are Muslim as the majorities and the Christian as the minorities, and vice versa there are Muslim as the majority and the Christians as minority. With a research paradigm focused on conflict study, the segregation of religious communities in the conflict of worship houses in North Sumatra after reform is seen. As a result, there are three zones of territory categories: green, yellow and red. Green category is the conflict of worship house in the area does not occur even though the level of diversity is high enough. The yellow category is there is a burden of unresolved worship houses conflicts in the area, and the red category is there has been an existing worship houses conflict. The dominant conflicts of worship houses occur because the regulations on the construction of worship houses are often not used as a reference. The conflicts worship places occur in the areas where the majority-population composition is a minority. In a predominantly Christian area, the conflicts worship houses occur due to the cultural shock. In Muslim-majority areas, the conflicts of worship houses are caused by regulatory problems and inter-ethnic cultural diplomacy degradation.
\end{abstract}

Keyword: Al Quran; worship houses; conflict and diversity; reformation

\section{INTRODUCTION}

North Sumatra is one of the provinces in various populations' demography; this is marked by the dominance of one region with certain ethnic and religions. In some districts/cities, the composition of population based on ethnic and religious is clearly visible. The dynamics movement of the society culture always occurs because of the contact with the outsiders. This contact is due to the interaction and communication that cannot be avoided; eventually the dynamic, elastic culture undergoes various changes. The intercultural contacts will become more complex when they are followed by religion contact. This contact will experience its point of complexity when the religion differences meet in one culture. The religion has its own space and culture and also has its own space. The dialectics of religion and culture will influence each other, and will form a culture of its own. One thing that can be ascertained naturally in various societies either culturally or religiously is the conflict, the different instinctive nature of human often and always creates opposition; this is due to the inability to understand that the difference with all its forms is a necessity.

The people of North Sumatra as a community which consists of different individuals, either in cultures, beliefs, thoughts or even interests, have a tendency to have friction, intersection and collision. The intersections and even the collisions occur when the interactions in the social spaces where different individuals meet to complement each other's needs. The interaction patterns will occur easily when it is done in a homogeneous community, while in a heterogeneous society the conflict will often occur. The conflicts that usually appear in two different forms can appear in latent form (hidden and invisible on the surface) and in the form of a manifest (open and easily known). After the reform, religion social conflict occurred in many places, in Manado, Central Kalimantan, West Kalimantan and several other places with different conflict variations. In many studies and research findings indicate that the fall of the new order regime changed the entire political landscape in Indonesia. The various ideologies, identities and interests that were previously suppressed then appeared on the surface. In the emergence competition in the public scene, there are friction and communal conflict based on the religion, racial and ethnic lines. In particular, the pattern of conflict on the basis of religious issues which linked the ethnicity in North Sumatera after the reform shows a significant increase. The data from Forum Kerukunan Umat Beragama (FKUB) or the Forum of Religious People Harmony of North Sumatera released at least a religion-based conflicts happening almost every year.

The conflicts of worship houses in North Sumatera have increased along with the increase of religious segregation in various interests; these could be either in economic competition, politics or up to the conflict of religious ideology thought both internal religion and external religion. The notes on the field of FKUB based on the latest data that can be found stating that there is a red line indicating the conflicts of worship houses have 
occurred and the opportunity will increase. There is a green zone, where the conflicts of worship houses do not occur even if the religious diversity exists in that location. There is a yellow line in which the potential for conflict of worship houses in that region is so strong, with various symptoms appear. There is a red line where in this region the conflicts of worship houses have taken place. The spread of conflict of worship houses based on these three categories becomes the focus of this research. The typology and characteristics of worship houses conflicts, the potential conflicts that have arisen and become embers in chaff and the conflicts of worship houses that have occurred in the past 18 years. The study and analysis conducted tries to map the dynamics of religious diversity based on the spread of worship houses conflict in North Sumatera Province as well as the changes that happened as a result of the conflict.

\section{THEORETICAL PARADIGM}

The social conflict as an expression can explain the various phenomenon of conflict that is always latent and manifest. The conflict of worship houses in this case is also latent and manifest in which religion plays an important role to increase either escalation or desolation of a conflict. In a plural society, conflict is an inevitable part. The fact is over the centuries, the differences in plurality have led to violent and long-standing conflicts. In a plural society from ethnic and religious aspects such as in North Sumatra, the socio-religious issue is not a simple matter. The relationship among the religious people and inter-religious people are always faced with a conflict that can arise at any sudden time. The relationship of inter and among religious people are not always harmonious, but they are often colored by conflict relationship, because religions have multi faces, besides there are certain institutional interests, powers and interests, how high the social values contained by the interests. In a social conflict, religion plays an important role, because religion is the deepest element in culture and is very influential in society in relations with seeking the meaning of life. Moreover, according to the sociologist's view, religion is functional and also dysfunctional. Religion is functional means that religion is able to fulfill the social functions, such as psychological tranquility, social cohesion, and the sacral of social structure that maintains the internal balance of a society. Religion is dysfunctional means religion can be a force that scatters, destroys, if it is used to develop the sentiment in a social conflict. Another term is religion is paradoxical, ambivalent, double faced, on one side it teaches the kindness, peace and love, but on the other side it teaches violence and hostility. According to Otto, the social function of a religion is varies, greatly depends on the historical background, the structure and the articulation of certain societies and religious systems.

From the two forms of understanding that conflict has two forces, constructive and destructive, it can be studied through several theoretical conflict views: 1) the absence of conflict in a social relationship cannot be a guide that the relationship is stable and secure or free from potential conflict. In a democratic government Rene Klaff states that the basic assumption of a democratic government form is that the society is actually conflict-ridden. According to him, although democracy requires a conflict, but democracy also requires a consensus. In another term Fankin Dukes states that in a democratic society, conflict is the basis for social change. According to him, although democracy needs conflict, but it also needs consensus. 2) In a plural society, conflict is not a sign of an imbalance, but as a sign of the balance mechanism process. The group boundaries are through conflict with other groups, in which a group defines itself in the struggle with other groups. The conflict with other groups contributes to strengthening the group identity. The conflict situation also will encourage the efforts to strengthen solidarity within among its members. 3) Conflict can be said to be productive in two levels; First, if it accompanies the occurrence of modification and creation of law. It means that during the conflict, new rules continue to be raised and the old rules are modified. Weber, Lewis Coser who state that the conflict of interest indeed leads to the emergence of creations and legal modifications. Second, the application of the new rules leads to the growth of new institutional structures which centered on the implementation of the new rules and laws.

From the above assumption it can be explained that social conflict will always exist, either religious and non-religious conflicts, therefore what can be done is how to control the conflict between different opposing groups will not be realized in the form of destructive conflict or form of violence.

The theoretical description of the conflict above illustrates how exactly the shape and pattern of the conflict occurs. It means, from the paradigm of conflict in the community, the process of peace establishing must be a partner for the conflict that is also always present in the midst of human life. The process of peace establishment will be effective when nonviolent processes are also applied in parallel. In the research on cultural strategy in the process of peace establishment and non violence the researcher uses two important theoretical frameworks, namely peace establishment and non violence.

The phenomenon of conflict which is backed by the religious factors, from the past until now always occurs in various parts of the world, including Indonesia and in the other regions which is more visible on the surface. These conflicts are likely to be widespread because of the increasingly globalized effect of information from different parts of the world that can be accepted by the religion believers. 
The plurality of social institutions in the society is one of the relevant media for strengthening the integrating between groups within a heterogeneous society. Integration is the control of conflict and deviation in a social system. In another sense, integration is a condition that shows the regularity of the interdependence of coordinated behavior within a social group.

\section{DISCUSSION}

\section{Religion Demographics of North Sumatra}

North Sumatera generally has an original ethnicity; some researches mention the original ethnics are Malayan, Karo, Pakpak/Dairi, Simalungun, Batak Toba, Angkola, Mandailing and Nias. Each ethnic group has its own culture, and even certain ethnic groups are dominated by certain religions. Besides the strength of cultural difference plus with religion, then the diversity always creates great potential for conflict. While other ethnics such as, Aceh, Java, Bugis, Ambon, Minangkabau, China, and India are other immigrants.

The religion demographic of North Sumatra viewed from religion will appear ethnic identification as certain religion believers such as Islam is majority adopted by Melayu, coastal, Minangkabau, Java, Aceh, and Batak Mandailing, Batak Karo, Simalungun and Pakpak around 65.45\%. Protestant and Catholic Christians are widely embraced by Batak Karo, Toba, Simalungun, Pakpak, Mandailing and Nias around 31.30\%. Hindu is widely embraced by the Tamils in urban areas, especially in Medan about $0.19 \%$. Buddhism is embraced by the Chinese ethnics who live in urban areas in North Sumatra Province, about 2.28\%. The Khong Hu Chu religion is also widely embraced by Chinese ethnics in urban areas, including Parmalim which is embraced by some Batak tribes in HutaTinggi, Kecamatan Lagu Boti, Kabupaten Toba, the figure is about $0.14 \%$.

\section{The Conflict of Worship Houses: The spread of Green, Yellow and Red Zones}

The government through the Ministry of Religion Affairs and the Ministry of the Domestic Affairs at the time issued the Joint Regulation of the Minister of Religious Affairs and the Minister of Domestic Affairs No. 9/2006 and No.8 / 2006 (PBM No. 9/2006 and No. 8/2006) in which the contents regulate the construction of worship houses. But in reality, the religion conflicts still occur and the number is growing. This fact can be seen from various data which are released by a number of institutions. According to the Centre for Religious and Cross-cultural Studies (CRCS) UGM, in 2008 there were at least 12 conflict cases around the worship houses. While in 2009 there were 18 cases and in 2010 there were 39 cases. One conflict case on the worship houses that attracted the public' attention is the case of Batak Protestant Church (HKBP) Ciketing, subdistrict of Mustika Jaya, Bekasi. This case occurred on 12 September 2010 that caused two leaders of HKBP Ciketing were treated intensively in the hospital because of being persecuted by members of the Islamic Defenders Front (FPI). Most of the problems about worship houses are the establishment of synagogues where the licence of it was the main cause. The conflicts of the establishment of worship houses almost are motivated by the refusal of certain religious groups on the existence of a worship house that is considered disturbing the public. In addition, the conflicts of the establishment of worship houses are also motivated by the argument that the building or the development plan was inappropriate or violated the spatial concept. The spread of the worship houses conflict area in the mapping is based on three zones, they are green, yellow and red zones to see the diversity of the region as well as to map how the dynamics of worship houses in the post-reform period. The Khoiri's research above does not specifically map the conception zone region based on the level of religious issues, particularly the worship houses. The determination of the zone region is based on the situation and the level of religious conflicts that have occurred in an area. This identification at least refers to the data released by the FKUB of North Sumatra and some research institutions released a report with the issue of worship houses. In its determination, the researcher considered the optimum level of escalation of the conflict, so that it could be categorized as an area with green, yellow and red zones in the management of the worship houses.

The green zones as the category of areas where the level of religious tensions, especially the conflicts of worship houses are not detected or have not found any potential conflict yet. The green zone category areas include the areas where the demographics are predominantly Muslims and Christians. In some areas, the life of religion community is protected from crucial issues related to the problem of relationships and religin symbols such as worship houses. The yellow zone is an area which according to the mapping of FKUB of North Sumatra with religious social issues belongs to the category of area which already has been detected to have conflictual burdens, especially the unresolved conflicts of worship house. The areas occur in several urban districts, such as Medan City, according to FKUB records in Medan City there are at least two problems of worship house. First, the problem of a mosque with Al Hidayah Mosque and Mosque in Plaza Hermes area as the developers in which the two mosques faced the complicated problem that has not been completed for many years because there is no agreement between the developer with some religion groups who required no displacement or no change of the mosque. Second, the regulation issue of the worship house construction, one of them is the construction of a new church in the district of Helvetia which is allegedly not in accordance with the regulation of .... the construction of Vihara in Medan Belawan also allegedly did not meet the rules of establishment. 
In the district of Batubara, a number of churches were on the making a railway line that leads to the port of Kuala Tanjung. Until now there is no settlement. In Tebing Tinggi, the problem of changing the buildings into worship houses. In the district of Deli Serdang, a church in the village of Laudendang which is located in Muslim settlements, is considered disturbing the comfort of the local community. The areas in the red zone category are determined by the occurrence of worship houses conflicts that have led to the act of destruction and the emergence of tensions which is over 10 years unresolved. There are three areas that are detected as red zone area related to the conflict of worship houses that is Tanjungbalai, there are 11 temples of monastery and pagoda burned mass in the middle of year 2016. The field records of FKUB of Tanjungbalai and the result of investigation of FKUB of North Sumatera Province explained that the continuing symbolic conflict between Islam and Buddhism in the case of the Amithaba Statue from 2010 to 2016 was in peak when a Chinese ethnic was considered to be an insult to one of the mosques.

Other areas that include in the red category according to the FKUB perspective are the areas of Binjai, especially Binjai Baru District which for more than 10 years the church has not yet been established. This is due to the tension between the local community and the presence of a church in the area. In the district of Deli Serdang which is adjacent to Medan City precisely in Laut Dendang Village, a church must be moved because when there was a widening it was not based on the rules, the surrounding community demanded that the church must be moved. The conflict has been going on for more than 10 years. The burning of worship houses and the Christians' houses in Sibuhuan, Barumun Sub-district of Padang Lawas Regency. They were used for worship. Many people galloped to the locations of the worship houses and quickly fired 1 (one) unit of worship house and 2 (two) Christians' houses, because they were not according to the rules. Similarly, Munawarah Sarulla Mosque of Pahae Jae District, North Tapanuli Regency has not been constructed since 2010 until now. For various irrational and unconstitutional reasons, the local government still does not grant the permission. It seems grudging and ignorant, and it also triggers a mass conflict.

The clashes between Nias tribesmen in Dusun Adian Nagoti with Tolang villagers, Sayurmatinggi subdistrict of South Tapanuli, North Sumatera, occurred on Monday, December 23, 2013. At least 10 houses and a worship house belong to Nias people were burned. The villagers of Tolang Jae were allegedly angry because Nias tribesmen cultivated the land and the construction of the houses on the forest area register 6 Angkola. They were disappointed, until finally, the villagers of Tolang attacked the settlement of Nias tribe.

The constructions of al-Khairiyah mosque and Mosque Raudhatul Islam in Yos Sudarso Village Silalas West Medan stood an elite house on the land belong to the government. Not only possed the state assets, the land mafia also destroyed the mosque. The establishment of GKPS Church in Buntu Pane Village, Buntu Pane District, Asahan District that caused the public worriness in Buntu Pane Village Buntu Pane Sub-district of Asahan Regency due to the construction of GKPS Church which did not meet the administrative requirements.

The construction of GBKP Church in Gung Pinto Village, Naman Teran District, Karo District caused the residents' objections to the construction. The construction of Meitreya Jaya Vihara in Tebing Kisaran SubDistrict of West Kisaran Town, Asahan Regency that caused the existence of a rejection letter from Indoesian Ulema Assembly (MUI) of Asahan district due to the construction of the Vihara which was close to the Great Mosque of Kisaran. The Ministry of Religious Affairs of Asahan has not $t$ issued a recommendation yet for the construction. The house used for worship of GBI Antiokhia Church at Indah Permai Housing Complex at 02 sub district ovf Bandar Utama of Tebing Kota, Tebing Tinggi caused the objection of the Housing Complex residents to the activities of the GBI Church. Ther Hall of Medicine that served as a monastery in the Tanjung Balai caused the community objection due to the building permit as a medical center previously but it was used for worship.The construction of HKBP Church of Binjai Baru Kota Binjaicaused the objection of residents in II Jati Makmur sub district of Kota Binjai. The FKUB administrators of Kota Binjai and the FKUB Advisors of Kota Binjai at a meeting on June 2, 2008 agreed that the settlement of this matter was handed over to the Kota Binjai government, and now the conflict still holds the fire, because both parties are still adhering.

The construction of Balaji Venkateshwara temple on Jalan Bunga Wijaya Kusuma no. 25 A Ex. Padang Bulan Selayang II Medan City caused the people's objection. The construction of Amithaba statue at Tri Ratna Vihara in Tanjung Balai caused the public demanded that the statue be removed. Since 2010 the potential conflict is as fire in chaff, and the burning of worship house in July 2016 ago was the anti-climax, because of the omission and the unstrict government. The attacks committed about 300 people against Muslims and the destruction of worship houses in the village of Melayu Selambo Desa Amplas Kecamatan Percut Sei Tuan of Deli Serdang Distrcit and threw at al-Barokah mosque, and burned five houses, and damaged the community plants. The burning of a mosque in Lumbanlobu Toba Samosir on July 27, 2010. The burning of two mosques in Aek Loba Village Aek Kuasan Sub-district, Asahan District, March 30, 2011.

The presence of a worship house often disturbs the inter-religious relationship, or even triggers a conflict because its location in a community that mostly adheres to other religions. The worship house in this context is seen not only as a place for worship or religious activity but also as a symbol of existence, a religious group. The problem becomes complicated if the number of worship houses is viewed by others not based on the 
necessity, but for the benefit of spreading the religion in other communities. The cases related to the destruction of the worship house become one of the factors behind the SKB of Ministry of Religion Affairs and the Minister of Home Affairs No. 1 of 1969 which was subsequently refined and replaced by the Joint Regulation of the Minister of Religious Affairs and the Minister of Home Affairs No. 9 of 2006 / No 8 of 2006 dated March 21 2006. Religion diversity creates its own dilemma. On one hand it contributes a positive effect to the development of the nation. But on the other hand the religious diversity can also potentially be a source of conflict in the future. Which of these potentials is dominant? Any conflict can happen. The cause of conflict is sometimes caused by a truth claim. But the dominant one, conflict is more triggered by the elements that are not related to the religion teachings at all. The real conflict is triggered by economic, social and political issues, which then blow up into religious conflict.

Observing the dynamics of religious communities in North Sumatra after the reformation, the reality is the religious people is faced with a number of disturbances of harmony and potential conflicts, both vertically and horizontally. The research results of FKUB in North Sumatera in the last five years show the conflict among religious believers in North Sumatra is caused by several factors, such as: religion blasphemy and harassment, religious conversion, constructing of worship houses, security, political dynamics, seizure of natural resources, discrimination developers behaviors, and no the less important one is due to the agrarian conflict. Among those conflict roots, the most dominant is caused by the construction of worship houses, the conflicts of economic resources seizure and agrarian conflicts, and then caused by the negligence or indecision of the government to enforce the regulation. The uniqueness of diversity in an area such as in North Sumatra, if it is laid out well it will be able to bring various benefits for the people's lives. But on the other hand it can cause a source of social tension. Therefore, the pattern of development in this area needs to be designed with great care, because if it is done with an approach that does not pay attention to social diversity, it will certainly lead to the undesirable results. A history necessity that in North Sumatra becomes an area of religions, and cultures meeting that touch each other. Such contact can lead to the conflict that can tear the nation integrity. Therefore, if the conflict is not properly managed, it will endanger the national stability.

\section{CONCLUSION}

The map of religious diversity in North Sumatra province especially in relation to post-reform worship house conflicts, explains that areas with a high degree of religious diversity do not always cause inter-religious tensions. The emergence of worship house conflicts is caused by two important factors, the problems of rigid regulation of worship house and intercultural communication that do not find the right formulation due to the movement rate and the arrival of different religions and ethnic communities in a region with quite high tension. The wave of urbanization in the cities of North Sumatra province has also caused new problems, because the population movements also follow the movement of cultural infrastructure and religion. The worship house is part of the community needs and the fulfillment of those needs is guaranteed by the Constitution. Therefore, the improvement and the regulation structuring of worship houses should be reviewed so that the fulfillment of the right to have freedom of religion can be fulfilled by the government.The mapping with regional classification pattern based on green, yellow and red zones is an effort to identify the spread of worship house conflict that occur in North Sumatera Province so that the conflict prevention and management can be implemented effectively.

\section{REFERENCES}

[1] Adam Kuper \& JessicaKuper, The Social Science Ensyclopedia, alihbahasa: HarisMunandar, dkk. (Jakarta: Raja GrafindoPersada 2000).

[2] Amin Abdullah, Studi Agama, NormativitasatauHistoritas ?,(Yogyakarta; PustakaPelajar Offset, 1996).

[3] Betty R. Scharf, The Sociological Study of Religion,alihbahasa: MachnunHusein, "KajianSosiologi Agama (Yogyakarta: TriaWacana, 1995)

[4] Clifford Geertz, The Religion of Java, (Berkeley; The Free Press, 1960).

[5] Clifford Geertz. Interpretation of Cultures. (New York: Basic Books, 1973).

[6] Elizabeth K. Nottingham, Religion and Sosiety, alihbahasa: Abdul MuisNaharong, "Agama danMasyarakat", cet. 7 (Jakarta: Raja GrafindoPersada, 1997).

[7] Franklin Dukes, Resolving Public Conflict: Transforming Community and Governance (Manchester University Press, 1996).

[8] Koentjarningrat. Sejarah Teori Antropologi I. (Jakarta: Universitas Indonesia Press, 1987).

[9] Lewis A. Coser, The Function of Social Conflict (New York: The Free Press, 1956)

[10] M. Amin Abdullah, dkk. (ed), AntologiStudi Islam: TeoridanMetodologi, (Yogyakarta: SunanKalijaga Press, 2000).

[11] Nasikun, SistemSosial Indonesia, cet. 9 (Jakarta: RajaGrafindoPersada, 1995).

[12] New Comb, et. Al. PsikologiSosial, (ed.)Ny. YoesoefNoersjirwan, (Bandung; CV. Dipenogoro, 1978). 
[13] Noorhadi Hasan, Laskar Jihad, Islam, Militancy, and the Quest for Identity in Post-New Order Indonesia. Terjemah Hairus Salim, Laskar Jihad, Islam Militansi, dan Pencarian Identitas di Indonesia Pasca-Orde Baru. (Jakarta: LP3ES-KITLV, 2008)

[14] Otto Maduro, Religion and Social Conflicts (New York: Maryknoll, 1982).

[15] Roger M.Keesing, Antropologi Budaya, (Jakarta: Erlangga, 1999)

[16] Sartono Kartodirjo, Pemberontakan Petani Banten 1888, ( Jakarta ; Pustaka Jaya, 1984).

[17] SoerjonoSoekanto, BeberapaTeoriSosiologiTentangSturukturMasyarakat, (Jakarta; RajawaliPers, 1983), h. 157.

[18] SukariaSinulingga, Dkk, Pelestarian Adat Masyarakat Etnik Sumatera Utara, (Medan: Forum Komunikasi Antar Lembaga Adat Sumatera Utara / FORKALA SU, 2004).

[19] Syafa'atun Elmirzana, dkk, Pluralisme ,KonflikdanPerdamaian: StudiBersamaAntariman, (Yogyakarta: Interfide, 2002).

[20] Zaenal Abidin Bagir, dkk.,LaporanTahunanKehidupanBeragama di Indonesia Tahun 2008 (Yogyakarta: CRCS UGM, 2009). 